\title{
An Early Attempt at Unifying the Universe: Suhrawardī's Concept of Miqdār ${ }^{*}$
}

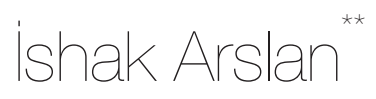

The prime matter of the elemental world is selfsubsistent miqdār [magnitude].

Suhrawardi, The Philosophy of Illumination, $p .56$.

\begin{abstract}
Though sharing the general framework of twelfth-century Islamic thought and classical cosmology based on the theory of emanation in common with the Peripatetic school, Illuminationist philosophy diverged from it in conceptual and methodical terms and thereby acquired the self-identity of an original system of thought. Criticizing the Peripatetic theory of matter for being based on the concepts of matter and form, Shihāb al-Dīn Suhrawardi (1154-91) conceived a theory of body based on miqdār (magnitude) in order to supplement his designation of the universe captured in the notion of nür (light). In accordance with the goals and motives of its time, this study analyzes his attempt with respect to the problem of defining the body, its constituents, and differentiation, and individuation. Isolating the body from non-sensible constituents and determinants (e.g., matter and form) and reducing it to sheer quantity, the Illuminationist theory of matter is viewed as an early attempt to transcend the Peripatetic dichotomies like matter-form, intellect-intelligible, sublunary-celestial, and so on in order to unify the corporeal universe.
\end{abstract}

Keywords: Incorporeal light (nūr), Magnitude (miqdār), Illuminationist theory of matter, Matter-Form, Peripatetic theory of matter, Perfection and deficiency.

* I would like to thank McGill University Institute of Islamic Studies for its support, İhsan Fazlıoglu for his favor and invaluable suggestions, and $\mathrm{H}$. İbrahim Üçer for his contributions.

** Assist. Prof., Istanbul Şehir University, Department of Philosophy. Correspondence: ishakarslan@sehir.edu.tr 


\section{Introduction}

his article focuses on the concept of miqdār, which, I argue, was central to the Illuminationist school's conception of the corporeal universe, as it was employed in Suhrawardī's masterpiece Hikmat al-ishrāq (The Philosophy of Illumination). ${ }^{1}$ As the point of departure, we may pose the following types of questions: To what degree does the conception of the body based on miqdār differ from the body based on matter-form? Given the probable differences, can we speak of a self-contained Illuminationist theory of matter that is distinct from the Peripatetic theory? What accounts for Suhrawardi's serious objections to the Avicennian system, which offers a fairly reasonable explanatory framework, at least for the twelfth-century intellectual world, ${ }^{2}$ and his effort to reconstruct the body on the basis of miqdār. ${ }^{3}$ Finally, can one interpret the monist system that Suhrawardì pursued at the axis of nūr-miqdār as an early attempt to unify the corporeal universe in the classical sense, namely, as divided into two by quality, as ethereal-perfect-super lunar and elemental-changeable-sub lunar? In light of these questions, the Illuminationist concept of miqdār is analyzed under three headings: "The Definition of

1 While I reviewed various works that incorporate translations and commentaries of The Philosophy of Illumination, the main source of reference is the edition by John Walbridge and Hossein Ziai of the Arabic text and English translation. Cf. Suhrawardī, The Philosophy of Illumination: Hikmat al-Ishrāq: A New Critical Edition of the Text of Hikmat al-ishrāq, ed. John Walbridge and Hossein Ziai (Provo, UT: Brigham Young University Press, 1999). For the quotations and interpretation of concepts, I took into consideration al-Shirāzī's commentary and the Turkish translation of the Hikmat al-Ishräq. Cf. Quțb al-Dīn al-Shirāzī, Sharh Hikmat al-Ishrāq, ed. 'Abdullāh Nūrānī and Mahdī Muhaquqiq (Tehran: Mu'assasah-i muțāla āt va taḥqịāt-i farhangī, 2002); Sühreverdi, İşrak Felsefesi: Hikmetü’l İşrak, trans. Tahir Uluç (İstanbul: İz Yayıncılık, 2009).

2 For a summary account of the comparison of Peripatetic and Illuminationist thought with respect to Suhrawardi’s criticisms, cf. Majid Fakhry, "Al-Suhrawardi’s Critique of the Muslim Peripatetics (alMashshā'un)," in Philosophy, Dogma and the Impact of Greek Thought in Islam (Aldershot: Variorum, 1994), 279-84. For his criticism of Avicenna in a generic sense, cf. Tahir Uluç, Sühreverdi'nin İbn Sina Eleştirisi (İstanbul: İnsan Yayınları, 2012), 59-75.

3 Aside from some remarks by Ziai, there is no substantial mention of the notion of miqdār's centrality in the Illuminationist philosophy and its later influence in the secondary literature. This also applies to the Illuminationist conception of time and history, as well as to Suhrawardìs political opinions and political philosophy. We could regard all of these as significant lacunae. Noting the influence of Illuminationist ontology on the basis of miqdār, especially on Ottoman philosophy and science, İhsan Fazlıoglu states: "Another challenge to Avicennian philosophy came from the Ishrāqiis (illuminationists) whose ontology conceived of the Universe in terms of geometrical magnitude (miqdār). The origins of this idea were contained in the Kitāb al-mu'tabar fi al-hikma by Abū al-Barakāt al-Baghdādī (d.547/1152), who however, did not elaborate on it. It was within this framework that Ishrāqii ontology could provide a framework for mathematicians to confidently construct their objects and knowledge based on those objects." Cf. İhsan Fazlığlu, "Between Reality and Mentality: Fifteenth Century Mathematics and Natural Philosophy Reconsidered," Nazariyat, The Journal for the History of Islamic Philosophy and Sciences 1, no. 1, (November 2014):1-39, p. 14. 
the Body," "The Constituents of the Body," and "The Differentiation/Multiplication of the Body." I also contend that the concept of miqdār functioned as a quantifying mirror reflecting the transcendent One (the Light of lights) in multiplicity.

Still subscribing to a mostly Peripatetic frame of analysis in his Al-Talwīhāt al-lawhiyya wa al-'arshiyya, Kitāb al-lamahạt, and Partaw-nāma, ${ }^{5}$ Suhrawardī turned what seemed to be clues in his mature works into a semi-autonomous system that later on would be entitled the "philosophy of illumination" in his Hikmat al-ishrāq, which he completed just before his tragic death. ${ }^{6}$ This work's three main parts remarkably reveal the three steps he pursued to first dismantle and then reconstruct this system in order to build his own. In the first step, summarizing the principles of thinking, he prepares the ground of reasoning (logic) that will legitimize the modifications and innovations he will introduce. In the second step, he develops a new theory of matter (physics) on this purified and leveled ground. And in the third and final step, he tries to establish a unified, whole universe (metaphysics) based on the conception of nür compatible with these two categories and as a natural consequence of them.

Considering the historical context within which Suhrawardi was vocal and the legacies he inherited, ${ }^{7}$ the Peripatetic school clearly was at the opposite pole in the debate on the body. Like all other advanced and complicated philosophical systems, the Avicennian system paid a high cost with respect to its ultimate goals. Aware of the difficulties of operating such a complex and minute system, one comprised of matter, form, and nature (physis) within corporeal entities; celestial spheres, separated intellects, and heavenly souls; and the faculties of the human soul in psychology in order to reconcile different ontological levels, Suhrawardī seeks more reliable means to acquire true/certain knowledge by combining rational and empir-

4 The problem of the body in motion, which would make up a fourth heading, was treated in a separate article and thus is not repeated herein. Cf., İshak Arslan, "Radiations of Light, Alterations of Heat: The Ishrāqī Concept of Motion,” Dîvân: Disiplinlerarası Çalışmalar Dergisi 20, no. 39 (2015): 1-22.

5 Mehdi Amin Razavi, Suhrawardi and the School of Illumination (London: Curzon, 1997), xviii.

6 For general accounts of Illuminationist thought in Turkish, cf. M. Nesim Doru, Kamuran Gökdağ, and Yunus Kaplan, eds., Sühreverdi ve İşrak Felsefesi (Ankara: Divan Kitap, 2015); A. Kamil Cihan, "Sühreverdi ve İşrakilik," in İslam Felsefesi: Tarih ve Problemleri, ed. M. Cüneyt Kaya (İstanbul: İSAM Yayınlar1, 2013), 397-421. It would be a significant contribution to the field if the current studies and research on Illuminationist philosophy, which now focuses mainly on the mystical aspects of Illuminationist thought, as well as its metaphysics, theory of knowledge, tropes, and eschatology, would be extended to incorporate its post-thirteenth-century transformation and interactions, especially its reflections on Turkic-Ottoman thought.

7 The major sources that bred Suhrawardìs thought were ancient Persia and Zoroastrianism, certain aspects of Platonist and Aristotelian philosophy, the synthesis that reached maturity after the Abbasids' translation movement of the classical era's natural philosophy filtered through Neo-Platonism, and finally the Avicennian system that Suhrawardī himself followed until his more mature works. 
ical methods of inquiry. This primary pursuit, that is, the attempt to arrive at true/ certain knowledge through shortcuts without further complications or contradictions, ${ }^{8}$ necessitated a new, coherent theory of matter

The Illuminationist theory of matter taken into consideration - particularly through the concept of miqdār herein - is, in fact, fundamentally part of a wider network related to the basic questions concerning the classification of beings, its hierarchical structure, the cosmological procession of emanation, and the possibility of knowledge. The ontological scale in the Illuminationist perspective, following from the postulate of "each and all existing things substantially are nür," begins with the Light of lights (nür al-anwār) and follows proximate lights (nür al-aqrab), dominating lights (al-nūr al-qāhir), managing lights (al-nūr al-mudabbir), dusky substances (al-jawhar al-ghāsiq), and dark bodies (al-hay'at al-zulmaniyya), until it reaches the bodies (barzakh). ${ }^{9}$ Illuminationist metaphysics converted the three elements (fire is not considered a separate element) into enkindled elements ( $q \bar{a} b i s$ ) in terms of their translucence: earth is defined as opaquely enkindled, water as semi-translucently enkindled, and air as translucently enkindled. ${ }^{10}$

The Illuminationist order of being, which appears to contain different forms from the most supreme (the Light of lights) to the basest (body), in fact consists of the graded appearances/manifestations of a single ontological substance. ${ }^{11}$ In order to explain the sensory multitude and motion found in the corporeal universe, light is divided into light for itself (substantial), which would also mean animate, perceptive, and active, and light for another (accidental). The body, which corresponds to dusk or dark, is actually non-existent ('adam). Hence Suhrawardì says: "By 'darkness' here we merely mean that which is not light in its own essence." 12 Since incorporeal lights cannot partake of dark bodies, accidental lights exist in the intermediary zone located between them. There are also isthmuses between accidental light and absolute darkness. The Light of lights occupies the highest step of the order of incorporeal lights at one pole of the scale of being, which is sorted vis-à-vis the degree of perfection and deficiency, and the miqdār, located on the opposite pole, constitutes the lowest step of the order of corporeal bodies.

8 Suhrawardi, The Philosophy of Illumination, 4

9 The constitution and order of beings is treated systematically in the second chapter of The Philosophy of Illumination in particular, and all ontological levels are defined in terms of nür from the Light of lights, which does not need to be defined because it is evident and independent, to the barzakh. Cf., ibid., 76 156.

10 Ibid., 124-25.

11 Ibid., 77-79.

12 Ibid., 95. 
Attempting to overcome the tension between absolute unity and relative multiplicity, this conception may at first sight remind one of a dualism akin to that of the Peripatetic school due to its distinction between nūr and dark body (isthmus/ body/miqdār). However, there remains only a single self-subsistent substance (the Light of lights) in a perspective where the isthmus/body is the absence of light; all hypothetical substances/properties are reduced to intelligibles; and all physical objects are equipped with natures, principles, and forces, to miqdārs, which the Avicennian system regards as accidents. This attempt to free the body from undefinable, imaginary properties and reconstruct it in a homogeneous unity requires the overcoming of two main impediments, namely, prime matter and form, the basic principles of the Peripatetic theory of matter. According to this theory, dispensing with the form (i.e., the individuation of bodies by means of a particular differentia) results in discarding the possibility of differentiation and multiplication. But if one dispenses with the notion of prime matter, both the identification of basic elements through a common substance and the elemental interrelations, that is, transfer (intiqāl) growth-decay (kawn-fasād), and metamorphosis (istihāla), making up the kinds of motion, become impossible. Consequently, irreparable cracks emerge in the hierarchical, deterministic, and continuous universe envisioned by Avicenna. The Avicennian system requires matter and form while connecting the realms of necessary and contingent, as well as maintaining the permanence of the body's identity despite the continuous growth and decay of elements. But these two constitutive agents (matter and form) influence the bodies that they engendered in certain regards, at least at the level of principle, and by means of them all physical processes, from the motion of the celestial spheres to the seed's germination to the tree, are explained in an interrelated and consistent manner. The system is naturally organic and teleological.

In the Illuminationist system, however, geometric space is an inanimate, passive, and static surface. The body gains tri-dimensionality, and thus visibility, in the lowest degree of deficiency (dusk) when the incorporeal lights emanate from the source (the Light of lights) "illuminated" onto miqdārs. In this sense, miqdār is not the boundary of another thing, a qualitatively different mode of being, or a prime matter, but just a hypothetical, quantitative ground that could receive illumination and only reflect what had radiated from the source. Aside from operating like a mirror, in that the incorporeal lights are reflected in the course of differentiation and multiplication, the miqdār has no impact on the bodies' nature. Since the system in its totality lacks the properties of inner forces, tendencies, and organicity, it is not teleological. Following from this general framework, we can look closer at how these two systems considered the problems pertinent to bodies. 


\section{The Problem of Definition: What ls the Body?}

The gist of the criticisms related to the definition of the object scattered over the chapters of The Philosophy of Illumination is that "nothing can be known with Peripatetic principles." The arguments that can be gathered under two headings stress the aporias of the Peripatetic theory on the one side, and the contradictions originating especially from the premise of matter and form on the other. According to the rules of logic summarized in the introduction, the conditions of the correct definition of a thing are as follows: ${ }^{13}$

i. The definition should consist of qualities particular to that thing.

ii. The definition should be clearer than what is defined.

iii. The quality by which a thing is defined should be known prior to what is defined.

iv. If something is defined by another thing, the causal link making the relation should be mentioned.

Suhrawardi claims that the Peripatetic definition of the body ${ }^{14}$ meet none of these conditions fully: "The Peripatetics, however, affirm that particular things contain entities that cannot be sensed or intellected in their particularity, thus making realities unknown even after they are known." ${ }^{15}$ The source of the problem here is trying to define the body by means of hypothetical substances rather than essential properties that can be observed without intermediaries. This particular pursuit remained fruitless because one could not determine the essential qualities of the thing that was to be defined with exactitude, neither lacking nor extra, for matter and form, considered the body's two constitutive elements, violate the minimum conditions pertaining to the definition in every step: It cannot be determined how and to what extent the non-sensory matter and form are particular to the object being defined. (i) The essence particular to one thing would remain unknowable to the person who does not know it at any other place. If it is known with a thing other than the one with it was defined, it would not be particular to it. If the essence

13 Ibid., 8-16.

14 The object's quiddity is defined as "a single, continuous substance" or "a long, wide, deep substance," in the major works of the Avicennian corpus, especially in the second article's second section in Kitāb al-Shifä', whereby the length, width, and depth were interpreted along the principles of Euclidian geometry beyond their everyday senses. Cf. İbn Sina, Kitabu'ş-Şifa: Metafizik I, trans. Ekrem Demirli and Ömer Türker (İstanbul: Litera Yayınc1lık, 2004), 53-73. The atom-based theory of matter, the strongest alternative of the matter-form-based theory, is completely refuted, and thus it can be stated that Suhrawardī, in the section dealing with the atom's and vacuum's refutation, entirely adopts the Peripatetic arguments.

15 Suhrawardī, The Philosophy of Illumination, 63. 
is not perceived and comprehended with the senses, even though it was particular to that thing, it would remain unknown in the Peripatetic sense. ${ }^{16}$ Just as in the instance of "fire is a spirit-like element," matter and form are no clearer than the explanandum. (ii) Therefore, matter and form remain unknown both anterior and posterior to the object defined. (iii) Finally, since the chain of links between the object defined and matter-form is unaccountable and inexhaustible, all operations and inferences based on them would be prone to the same imperceptibility (iv).

Suhrawardi does not go beyond these above-mentioned criticisms and propose an alternative formula based on Illuminationist principles and proper to the rules and conditions of the correct definition because (1) he was unable to develop an all-inclusive, standard theory of definition in the Peripatetic sense due to the structural limits noted above and (2) the Illuminationist theory of knowledge, based as it is on beholding (mushāhada), does not require such a definition. As regards the notion of blackness, he says:

\footnotetext{
The truth is that blackness is one simple thing. It can be intellected and has no unknown part. It cannot be defined as it is to someone who has not beheld it, but anyone who has beheld it has no need for a definition. Its form in the mind is like its form in sensation. Such things have no definitions. Rather, the compound realities are known from the simple realities: one conceives the simple realities separately and knows the compound by uniting them in a single subject. ${ }^{17}$
}

Objecting to the Peripatetic claim that the answer to the question of "What is that?" intended for that thing's quiddity (māhìya), which involved substances that modify the truth of a thing and that this modifying things had to be forms because the accidents could not modify the answer to the question of "What is that?" Suhrawardi underlines that the accidents modified the answer to the question of "What is that?" contrary to what was supposed. For example, if someone asks "What is that?" pointing at a house, the answer is not the elements like mud and stone of which the house is composed, but rather the house that is formed by synthesizing the elements and transforming them into a new kind. Accidents can modify the answer to "What is that?" without recourse to hypothetical determinants, solely with the mode of aggregation ( $F a$ al-ä'rād mughayyirat jawāb " $m \bar{a}$ huwa"). ${ }^{18}$ Therefore, there is no need for assumptions, the truth of which we will never know, in order to answer the question of quiddity, for the accidents themselves would suffice. 
As can be inferred from the example of the house, there is no qualitative difference between the house and the brick since complex realities can be known by means of simple realities. One can imagine the simple reality as a single individual without mediation and definition, and can comprehend the whole by means of gathering the simple realities under one subject. ${ }^{19}$ Whether simple or complex, once it is proven that sole accidents could modify the quiddity, what remains is the status of the categories that link the proposition's parts and the object's adjectives - and they are all intelligibles. All universals like quiddity, unity, multitude, and the like, which have no concrete reality in the external world, are included in Suhrawardi's intelligibles set, ${ }^{20}$ among which "existence" and its synonyms have the greatest everyday use:

\footnotetext{
"Existence" is used with a single meaning and as a single concept for blackness and substance, for man and horse. It is an intelligible meaning more general than any one of these, as are the concept of quiddity taken absolutely, thingness, and reality taken absolutely. We claim that all these predicates are purely intellectual. ${ }^{21}$
}

Whether in relation to things as it was most often used in everyday life with the preposition in/at (e.g., to exist in time and/or in space) or a copula as in "John is a writer," or in the sense of essence/substance as in "a thing's essence, its being," Suhrawardī, who regards all modalities of being as intelligibles predicated on external quiddities, ${ }^{22}$ asks the ones who accept the reality of any mode of existence (except for the intelligibles) to explain in what sense and use it was employed. Also noting the probable misunderstandings of miqdār originating from its everyday use, Suhrawardī views it as metaphorical that the concepts of body and miqdār were not used interchangeably or that the incorporeal lights are described as unquantifiable and objects as "quantifiable things" in a manner that would recall an extra accident.

Just because we say that a body has a determinate magnitude, it does not follow that its magnitude is superadded to it. Realities do not depend on turns of phrase, for the latter are often metaphorical. Often a man will think of thingness with magnitude and say, "A body is a thing that has magnitude." (al-jismu lahu miqdārun). If he examines the reality, he will find that the thing is simply magnitude."23

19 Ibid., 52.

20 Suhrawardī mentions numerous examples over different chapters: All predicates, (e.g., darkness/colorful-ness, substance-ness) along with all categories (e.g., humanity, quiddity, existence, unity, - and hence deriving from it - numbers, contingency, necessity, affiliation fraternity, sorority, paternity) obey this proposition.

21 Suhrawardi, The Philosophy of Illumination, 45

22 Ibid., 47.

23 Ibid., 56. 
As the problem of the differentiation of bodies shows, there is nothing in the constituents of bodies consisting of states (hay'a) other than the "intensifying and weakening qualities," since the individuation of a body formed by accidents is provided by perfection and deficiency as in incorporeal lights (Fa bāqiyya al-kayfiyya allati tashtadd wa tad' 'af). ${ }^{24}$ Thus, what remains after discarding the opposite qualities (e.g., hot-cold, dry-wet) and determinants (e.g., matter-form) are the quantifiable units that can be "defined by differences of degree." This discussion of the body's definition deepens further with the question of what are the building blocks that actually make up the body.

\section{The Question of Constituents: What Are the Body's Building Blocks?}

In the Peripatetic theory of matter, all natural, sensory objects subject to growth and decay (alteration) are composed of principles, forces, accidents, and causes. The "fundamental principles" setting the basis of the formation of natural bodies are matter, which is the predicate of the substance and could take another form with the thing predicated, and form, which inhabits this locus and provides the object's quiddity. ${ }^{25}$ All probable conditions that may externally constitute an accident for the object (i.e., all categories that relate to objects and allow one to describe the transformational processes of growth and decay $)^{26}$ are classified as accidents. ${ }^{27}$ The Peripatetic system regards miqdār, the focus of our inquiry, as one of the accidents that relate to objects, just like time. This is Suhrawardi's primary objection to that system. In the Peripatetic interpretation, summarized in the article relating to the refutation of matter and form in The Philosophy of Illumination, ${ }^{28}$ "bodies are common in matter, and varies by magnitudes." Since miqdār, unlike matter (hay'ūlä), is considered a quality that can be increased or decreased and is variable depending upon the particular object, it is not included in the "reality of the matter." Considering the distinction made in the Metaphysics' third article, the body is both a single, continuous substance (inna al-jism jawhar wähid muttașil) ${ }^{29}$ and a quantity ( $\mathrm{kam}$ ) that corresponds to the expression continuous quantity at the same time (al-jism alladhī huwa al-kam fa-huwa miqdār al-muttașil). ${ }^{30}$

25 İbn Sina, En-Necat: Felsefenin Temel Konuları, trans. Kübra Şenel (İstanbul: Kabalcı Yayınları, 2013), 89; İbn Sina, Kitabu'ş-Şifa: Metafizik, 55.

26 İbn Sina, Kitabu'ş-Şifa: Fizik I, trans. M. Macit and F. Özpilavcı (İstanbul: Litera Yayıncılık, 2014), 40.

27 İbn Sina, En-Necat, 95.

28 Suhrawardī, The Philosophy of Illumination, 52.

29 İbn Sina, Kitabu'ş-Şifa: Metafizik I, 57.

30 Ibid., 99. 
According to Avicenna, while the body in this second sense is an accident (miqdār) related to matter, increases-decreases, and can only be distinguished from matter in estimation, it is the permanent substance in the first sense that of being able to receive tri-dimensionality. After taking both definitions of the body for granted, Avicenna goes on to explain all of the geometric concepts that are related to miqdār (e.g., line, surface, point, and angle) in relation with each other. What is left over in relation to the object's motion is time, which he again counts among the accidents and includes in the category of continuous quantity (al-kam al-muttasil) with the proviso that if each parcel of the continuous quantity is a fully received, permanent thing, then it is miqdār; if its existence is gradually generated (shay'an ba'd shay'), then it is time. ${ }^{31}$ In other words, the continuous quantity that is, in fact, a single quantitative form is called miqdār with the aspect of rest, and time with the aspect of change. Thus, while the accidents relating to the object (e.g., time, motion, and miqdār), are subject to the accidental changes of the kind of processes like increase-decrease and concentration-rarefaction, permanent substances are not subject to these sorts of changes/motions. The Peripatetic system tries to answer "How could the body remain itself when it is continually changing?" with the dual meanings of the body's definition and to preserve the stability of the matter's substance by relegating change and motion, taken to be "imperfection" in classical cosmology, to accidents that also include miqdār.

Natural forces are classified by their functions under three headings - objective, vegetative, and celestial - in the hierarchical cosmology extending from simple elements to separate intellects. In this classification, a distinct and unique natural force is designated for each form of motion, one that cannot be relegated to a more basic category. Thus motion, which in fact has to be unitary and uniform, is necessarily subjected to qualitative differences. What remains in order for the object - the formation of which is fulfilled by the synthesis of principles, accidents, and forces, and that gained mobility - to engender complex objects and superior structures are the external causes, which are divided into four, and at its most basic level as efficient and final causes. ${ }^{32}$ The potentials within the body emerge during the process of cosmic cycles in line with the dialectic of potentiality and actuality (dunamis) and the emanative mechanisms, which form the backbone of Aristotelian physics. When the body's propensity reaches the stage at which it can receive form in this eternal cycle, the form inhabits it and the process of embodiment concludes with the addition of accidents, including miqdār, at the last stage. What

\footnotetext{
31 Ibid., 103

32 İbn Sina, En-Necat, 92.
} 
the body has in actuality is its form, and what it has in potentiality is its matter in the dynamic and complex process of formation/perfection in the transition from potentiality to actuality. ${ }^{33}$ The body's actualization process continues until all of its potentials are actualized. In contradistinction with the vegetative and animal levels, only the human being has access to the active intellect and the possibility of perceiving the necessary being.

Adopting a mostly critical stance to the problem of definition, Suhrawardi goes a step further in the problem of the body's constituents and dispenses with all predicates and determinants that are not subject to sensation. Since there is nothing to sense beyond the accidental alterations of three dimensions, the body is "nothing but magnitude, and three extensions are the extent to which the sides of the body have gone in different directions." ${ }^{34}$ Since this definition reduces the body to sheer miqdār, no constituent can be added to it. "There is nothing in the elements but corporeality and states - nothing else!" 35 Thus, as the expression la ghayrihi indicates, the problem of the "body's constituents" is resolved by itself. The "extension" of this abstract and continuous space (miqdār) in three dimensions, or its meeting with other accidents, does not necessitate that miqdār be an ordinary accident (in the Peripatetic sense) among others. However, facing the difficulty of explaining the derivation of particular objects with individual qualities out of an absolute substance (miqdār), Suhrawardì draws a distinction, like the one in the Peripatetic system, between absolute substance (incorporeal miqdār) and the particular maqādir (e.g., length, width, and depth) and interprets these as its extensions. Hence, three dimensions make it possible for the body to be in a state of continuous change, and absolute miqdār provides the stability that preserves it as itself despite the continuous change in dimensions.

Suhrawardi exemplifies the distinction between the incorporeal and the particular (three dimensions) maqādir in the case of wax. Even though the three dimensions continue to change during the course of burning (i.e., the candle's parts assume different appearances, similar to the Peripatetic conception of prime matter, its "incorporeal miqdār-ness" remains the same. ${ }^{36}$ Following from what changes

36 Following Suhrawardi's wax example, Majid Fakhrypoints out the difference between the Illuminationist notion of miqdār and the Avicennian conception of contiguity, while noting the similarity of René Descartes' (d.1650) extension and how the example of wax is employed. Cf. Fakhry, "Al-Suhrawardi's Critique," 284 n. 11. Fakhry employed Descartes' wax argument in the second meditation in order to analyze the relation between the body's mutable properties and its immutable essence, as well as the 
and what remains, Suhrawardi defines "what a body essentially is" by saying that it "is nothing but magnitude, and the three extensions are the extent to which the sides of the body have gone in different directions (jawānib)." ${ }^{37}$

Claiming that the Peripatetics misunderstood the variation of miqdārs ( $m a-$ qādir) from one object to another, Suhrawardi suggested that they confused variation with the concept of contiguity, for instance, that qualitatively immutable maqādir only varied by perfection and deficiency. What is meant by speaking of the intensity of the light or heat is the intensification in their resistance/strength. Accordingly, light does not fade because darkness penetrates it or because dark matter mixes with it in an ontological sense, but because of light's deprivation in itself. This also applies to the three dimensions that make up the body. If there is a measurable difference between two lengths, this is because the longer one's length is closer to perfection/completeness. Besides, its "extra" length does not indicate the existence of any hypothetical substance or quality added onto the miqdār. Just as heat-ness is related to the heat's intensity, the shortness or length just consists of completeness or lack in the miqdār. ${ }^{38}$ Consequently, the "body is nothing but self-subsistent magnitude" (nafs al-miqdār al-qā'im bi-nafsih) and only the three dimensions can be thought of as a supplement to a body. ${ }^{39}$

If the miqdār/body is a quantitative substance consisting of three dimensions alone that neither increase nor decrease, how can one explain the facts of rarefaction-concentration? According to the Peripatetics, a water-filled container explodes when it is heated high enough due to the "increase in miqdār" of the liquid's volume, namely, the amount of water in the container. Refuting the proposition that rarefaction corresponds to the increase in miqdār and concentration to its decrease, Suhrawardi supposes that the heat's power pushes the water particles in different directions. Since there are no atoms and vacuums in the universe, contrary to the

relation between sensory data and knowledge. Cf., René Descartes, Meditations on First Philosophy, trans. Michael Moriarty (New York: Oxford University Press, 2008), 22-24.

37 Suhrawardi, The Philosophy of Illumination, 53. This continuous change, particularly with regard to miqdār, in different aspects in order to make up the body is problematic with respect to the possibility of knowledge, as Descartes would emphasize later on. One reason for Suhrawardi’s envisioning of an "imaginal world" between the incorporeal lights and the miqdārs might be his pursuit of a solution that would serve as a place for the permanent archetypes that he needed to provide for the possibility of knowledge and assume the role of the active intellect. Since the permanent change and motion in miqdārs are fundamentally reflections of the order and relations of the incorporeal lights, the gap between the two qualitatively different fields might necessarily have required an intermediary with a preserving function, like the imaginal world. For a study on the imaginal world, cf. Fatma Turğay, "İşraki Felsefe Geleneğinde Misal Alemi: Sühreverdi Örneği” (Unpublished PhD diss., İstanbul University, 2016).

38 Suhrawardī, The Philosophy of Illumination, 54.

39 Ibid., 56. 
atomists' claims, the heated water's particles are inclined to move out; however, the explosion occurs because the container's sides act as a barrier against this strong tendency. In other words, the explosion's real cause is not the decrease in miqdār, as the Peripatetics suppose, but the fact that the elements move in different directions and the non-existence of vacuums, in contrast to what atomists claim. Rarefaction and concentration occur thanks to the rarefaction of the heated particles to composition-decomposition, which is due to the increase and decrease in heat and the intervention of a light element (e.g., air) in due course. ${ }^{40}$ Similar to the law of the conservation of mass, once the scattered particles are gathered, the object reverts to its first/old miqdār. According to the Peripatetic explanation, the possibility of absorbing and evacuating some of the air from a full bottle is due to the increase in the miqdār of the air that remains inside, and the possibility of water entering the same bottle when submerged in water upside down is due to the decrease in miqdār by concentration. Suhrawardi rejects both of these statements on the grounds that one cannot prove any increase or decrease in the miqdār of air with such experiments, which are almost impossible to be controlled. Just as experimental facts (i.e., the subjects of the Peripatetics' misinterpretations) show, the "body is magnitude and that the magnitudes of the world are neither increased nor decreased" (Inna al-jism huwa al-miqdār wa maqādir al-'ālam lā tazdad wa lā tanquș). ${ }^{41}$

Suhrawardī, who largely bases his claim to validity by refuting the existence of matter and form, devotes the next article to criticizing the notions of atom and vacuum. ${ }^{42}$ In plain words, the classical theory of the atom is based on the assumption that "the object should consist of miniscule, indivisible units since it cannot be divided ad infinitum; otherwise, infinitely divisible objects would keep on being divided forever, which is impossible." Suhrawardī opines that this conjecture is incorrect, because the division is not in actuality but in potentiality. Although it appears that the division keeps going on forever both in the mind and in the external world, there are no "real individuals" of division. Therefore, both division and the expression "individuals of division" are relational. For example, as one can classify the infinite numbers in the mind as hundreds and thousands, the infinity of one set does not contradict the infinity of another set.

Employing the current arguments of his time in his criticisms of the notions of atom and vacuum, Suhrawardī repeats the inconsistencies and internal contradictions of the "indivisible particle/atom" concept. Hence, once a particle is supposed 
to be in contact with two other particles, and given that these particles cannot be in contact with each other in all aspects, just a single point of contact would be picked up. The result of this would be the emergence of a difference between the points of contact and the points of no contact, and once such a difference occurs the atom/ particle would have already been divided. Consequently, one cannot claim indivisibility for a particle that possesses sides (all particles necessarily possess sides), for each contact between the two particles necessarily brings out sides and sides, in turn, bring in division. The notion of the existence of a vacuum, which is supplementary to the notion of an atom, cannot be spoken of in a space where objects are extended because objects (maqādir) just consist of miqdār (Fa-lā yumkin an yakūn mā bayn al-ajsām khāliyyan). As far as the existence of a vacuum is concerned, it has to be a miqdār as well, and therefore has to have three dimensions. In this case, it should not be called "vacuum" but "miqdār."43

\section{The Problem of Differentiation and Multiplication: How do Bodies Individuate?}

If miqdār is a single, simple, and continuous substance in fact, how can difference and multiplicity (tafāwut/takthīr) be explained? How could various kinds and individuals emerge from an incorporeal continuity? The other side of the problem is how a contingent category formed of corporeal elements (e.g., a body or accidents) would be related to a transcendent source. Trying to surmount the aporia of deriving contingent beings from an absolute and eternal source from within the theory of generation, without falling into Peripatetic dualisms, Suhrawardi had to introduce many significant changes to the system. ${ }^{44}$ According to the Illuminationist formulation of multiplication, "Just as one thing is more black than another through an intrinsic perfection in the black itself, not through something added to blackness, so likewise does an intensity and perfection distinguish necessary existence from contingent existence." ${ }^{45}$ More pointedly, nothing is "distinguished" from the absolute One (Light of lights) in fact, for such a distinction would require

\section{Ibid., 63-64.}

44 Making the layers forming the celestial order infinite, discarding separate intellects and souls, and multiplying the incorporeal lights out of the Light of lights are among such changes. For a comparison of the two systems from a cosmological perspective and the Illuminationist criticisms, cf. İshak Arslan, "Pushing the Boundaries of the Universe: The Criticism of Peripatetic Cosmology in Hikmat al-Ishraq and Its Commentaries," Nazariyat: Journal for the History of Islamic Philosophy and Sciences 1, no. 1 (2014): 129-55.

45 Suhrawardī, The Philosophy of Illumination, 67. 
a qualitative differentiation between the one that is distinguished and the source from which it has been distinguished. Carefully avoiding this, Suhrawardi explains all kinds of differentiation and multiplication by the perfection and deficiency of the same, truly single and holistic ontological substance (nür).

Therefore, the Light of Lights and the first light that results from It are only to be distinguished by perfection and deficiency" ${ }^{\prime 4} \ldots$... The intellectual, incorporeal lights differ by perfection and deficiency, not by species. ${ }^{47}$ (Ihtilāf al-anwār al-mujarrada al-aqliyya huwa bi al-kamāl wa al-naqșu lā bi al-anwā').

Perfection and deficiency, which means the key to the passage to the quantitative world, provide both the multiplication of the incorporeal lights (without hindering its ontological unity) and the definition of a single and continuous substance (miqdār) in terms of quantitative units. The Peripatetics state: "When heat intensifies, it does not change in itself by accident. Therefore, the intensification of heat is by a differentia." ${ }^{48}$ In Suhrawardì's opinion, this inference about the change of heat is incorrect, for what changes is the heat's "particulars" and "place," rather than the heat itself as an independent property. Since the answer to the question "What is that?" does not change and such a change could not take place by means of an accident, the difference between the heat's particulars does not come through a differentia (fașl). Thus, what distinguishes its particulars is only the differentiation of perfection and deficiency. ${ }^{49}$

According to Suhrawardī, the conception of universal heat-ness generally contains all of the heat's individuals without distinguishing them as perfect or deprived, for the change in the quality's intensity and weakness does not necessitate a change in its substance. Just as the qualitatively opposite categories of hotness and coldness of the Aristotelian physics was unified into a single and isomorphic scale of heat by being transposed into minus (-) and plus (+) in the quantitative idiom of modern physics, ${ }^{50}$ Suhrawardi removed the changes in heat from being regarded as a change in kind pertaining to the substance by employing the expression "the heat's individuals," which would later on be termed "degree," and thus turned

50 The concept of heat, defined in modern physics as "the average kinetic energy in a molecule of any matter," is, in a most general sense, the "intensity in heat." Compared to contemporary axioms, Suhrawardi's conception lacks the critical distinction between the concepts of temperature and heat. This was indicated by the theory of thermodynamics, which was engendered by precise distinctions between velocity-acceleration and heat-temperature. 
them into a quantitative category that could be defined along the scale of perfection and deficiency. Applied to the phenomenon of heatiness, this analysis applies equally to the miqdār's aspects of length, width, depth, and its other properties. ${ }^{51}$

Even though this differentiation of bodies/miqdārs from each other and their multiplication was provided at the scale of perfection and deficiency, the question of the individuation of miqdārs (without succumbing to forming similar and equal copies) remains. Recalling the Avicennian system, all bodies in the physical world are common in prime matter, whereas they are individuated by means of form into natures and predispositions. Trying to cancel out determinants like matter and form, Suhrawardī had to distinguish the conception of miqdār, like the distinction in the Peripatetic's theory of body, in order to resolve the question of differentiation and individuation in the elemental world:

The result of the argument is that absolute body is absolute magnitude and particular bodies are particular magnitudes. Just as bodies share in absolute magnitude and differ by their particular different magnitudes, so too they share in corporeality and differ in their particular divergent magnitudes. ${ }^{52}$

However, this arbitrary distinction concerning miqdār had to take into consideration the probable objections: Regardless of whether they are called absolute or particular, what really differentiates miqdārs from each other? If it is nūr, how could a simple, transcendent and autonomous being (nür), which is independent of any place and state, relate to and inhabit an abstract space? Next to this question, Suhrawardī focuses on the distinction between nür's finite and infinite aspects. In this vein, although the light's dominating aspect is infinite and unlimited in its influence, its managing aspect (nafs) is finite and limited. It is this finite-limited aspect that relates with miqdār. The necessary being is free from space due to the completeness and perfection of its substance, but the contingent being needs a place due to the lack in its nature. Once the category of perfection and deficiency comes into play as a key to quantification, the qualitative difference between the

51 Natural philosophers at Merton College (the University of Oxford), having focused on the question of quantification from the sixteenth century onwards, are very keen on "how the properties vary numerically along a constant scale." This process, which formed the basis of the scientific revolution (i.e., the "quantification of properties"), took centuries to transform temperature into a measurable property by grading the opposite ends between the freezing point (deficiency) and the boiling point (perfection) of water in a glass tube in equal increments. Today's "ordinary" thermometers, or their emergence with margins of error reduced to a minimum, were invented and improved upon during the eighteenth century. Cf. W.E. Knowles Middleton, A History of Thermometer and Its Use in Meteorology (Baltimore: The Johns Hopkins University Press, 1966).

52 Suhrawardī, The Philosophy of Illumination, 54. 
contingent and the necessary is, in the Peripatetic sense, absolved. From this point of view, the lowest point of the nür's privative aspect is accidentalness and referral to a place (Ghāya naqșih bi al-'aradiyya wa al-iḍaffa ilā al-mahall). However, "The deficiency of something does not imply the deficiency of that which is like it in some respect." ${ }^{33}$ The relation of the unconscious and inactive surface (body/miqdār) with the dominating and independent (ghani) lights that perceive the essence becomes tangled at this point, for the analyses concerning the relation between the perfect and imperfect necessarily raises the same question: Even if the privative aspect of a simple and autonomous substance (nür) is assumed, how could this aspect relate to "a thing" other than itself and engender a multitude from this single and simple thing? Suhrawardī answers: "The difference could be by magnitude, by number, or by intensity and perfection." ${ }^{4}$ Since the contiguity of accidents to them is no question, the differentiation of incorporeal lights is caused by the increase and decrease in their brightness. The change in miqdārs is made possible by both perfection and deficiency as well as by the different assortments of the accidents that are contiguous to the miqdārs.

This is unsound, for if a magnitude exceeds another magnitude, we cannot say that it does so by something besides magnitude. Magnitudes differ only by magnitude (Iz lā tafāwuta fi al-maqādiri, illā bi al-maqādiri). The difference is in respect to their being magnitude and because one is more perfect and the other more deficient. This is like the difference between the more intense and the weaker light or the more intense and the weaker heat. ${ }^{55}$

As can be seen from the problem of definition, all objects are constituted by accidents in miqdār-based physics, and all categories qualifying the object are regarded as intelligibles. However, finding the Peripatetic theory of knowledge unsatisfactory for adjusting the knowledge of the body to the determination of the middle term (i.e., the universal), Suhrawardì had to solve the problem of universals within the Illuminationist point of view. Since matter and form are refuted, and categories like "being" and "unity" are regarded as intelligibles, what would be the status of the universal forms, such as "humanity"? Either in the sense of Platonic archetypes or Aristotelian forms, the ancient traditions upon which he relied needed universal forms so that they could depend upon a transcendent constant that was free from growth and decay and could make knowledge possible through the relation of the 
universal and the particular. Cognizant of this problem, Suhrawardi refuted the existence of both universal and particular forms without opposing the received wisdom (i.e., that of the classical-era Greek philosophers and Persian sages):

Do not imagine that these great men, might and possessed of insight, held that humanity had an intellect that was its universal form and that was existent, one and the same, in many. How could they allow there to be something unconnected to matter, yet in matter? How could one thing be in many and uncounted material individuals? ${ }^{56}$

Since relational notions that represent multiple individuals, like tree-ness or humanity in the Illuminationist system, are not to be considered as universals in the Peripatetic sense, the only beings that can be so considered are the incorporeal lights. However, such lights gain the attribute of universality only with respect to their emanating into the world of miqdārs and relating to the quantities. Thus, removed from being a property of substance, the property of universality turns into a mode of relating to a miqdār. Then, a concept like "human form" only appears when an incorporeal substance (nür) comes into contact with the sculpture of the human (body) in the world of miqdārs. ${ }^{57}$ All other forms manifest, as in the case of the human form, through their contact with miqdār.

There are metaphors in the words of the Ancients. They did not deny that predicates are mental and that universals are in the mind; but when they said "There is a universal man in the world of intellect" they meant that there is a dominating light containing different interacting rays and whose shadow among magnitudes is the form of man. It is a universal - not in the sense that it is a predicate, but in the sense that it has the same relation of emanation to these individuals. ${ }^{58}$

While the real meaning of the universality that allows for different objects to be collected under general kinds is equality in radiance, the reason for multitude is not the Light of lights, but rather the miqdār. In other words, the multitude in the physical universe can be interpreted as the radiance (ishrāqāt) of the Light of lights on the miqdārs or its abiding by the quantitative units represented by the miqdārs. Closely perusing the passages that discuss the differentiation-multiplication (tafāwut) problem, it is noteworthy that multiplication in the elemental/isthmus world is juxtaposed with miqdār and quantity, and that multiplication in the luminous world is always acclaimed with the perfection and deficiency of light. 
Referring to a lamp metaphor in order to clarify the subject, Suhrawardi points out the distinction between the substantial light (flame itself) and the accidental rays of the lamp (rays of the flame). The surfaces reflecting the light rays (i.e., walls, the surfaces upon which the rays fall) serve as miqdār in this metaphor, and the substantial light radiating from the candle is the incorporeal nür. The incorporeal light, which radiates gradually by deficiency from a single source, refracts, differentiates, and multiplies "as soon as it comes into contact with" the physical world, and darkness (body) appears at the end of all these processes (i.e., at the minimum level of deficiency that it could relatively reach). This interpretation also sheds light on the problem of universals, because all kinds of determinations in the physical world are universal with respect to radiation and particular with respect to miqdār, and therefore different and multiple. Taken in this sense, miqdār stands for a quantitative surface that relates to the incorporeal light and provides the individualization and multiplicity of the bodies without any impact with respect to their qualities. This surface deprived of physical-material properties could be imagined as an abstract, conjectural basis rather than as a tangible substance, where nūr refracts by "contacting" the surface at the minimal level of opacity that it could reach and thus causes three-dimensional objects to gain visibility.

Suhrawardi's attempt to unify the universe involves resolutions concerning the problem of motion in addition to defining the body and the problems of differentiation and multiplication. According to this, the downward movement of the stone that was thrown into the air does not take place due to the body's inherent natures and tendencies, unlike the way it does in Aristotelian system. Both the rise of lighter smoke and the fall of rain are directly dependent on a managing light. Since the real cause of all motion attested to in the corporeal realm is the incorporeal lights' permanent control over the celestial spheres and miqdārs, linear motions that are subject to growth and decay are dependent on the celestial spheres' cyclical motions rather than on such indefinite forces as nature and tendency. The source of the heavens' permanent and cyclical motions is the continuous radiance of incorporeal lights. ${ }^{59}$

In this world, were it not for light - whether self-subsistent or accidental - no movement at all would occur. Thus, the lights become the cause of movements and heats and light is evident in both movement and heat. ${ }^{60}$

Since all motions in the elemental world that are subject to formation and decay are associated with heat-ness, the motions of animals and humans, which

59 İshak Arslan, "Radiations of Light, Alterations of Heat: The Ishrāqī Concept of Motion," 1-22.

60 Suhrawardi, The Philosophy of Illumination, 129. 
are regarded as willed, obey the same proposition. According to the Illuminationist system, celestial spheres and stars radiate at various intensities with regard to different aspects (e.g., managing, dominating, and accidentalness). Similarly, the variety in causes elicits the variety in radiation and their motions are differentiated with respect to rapidness, slowness, direction, and so on. Radiances (ishrāqāt) influence the motions and vice versa. While the radiance remains conditional upon motion, radiance also compels the motion. This process continues without falling into a vicious circle, for the radiance eliciting the motion and the radiance that results from it differ in quantity. ${ }^{61}$ These infinite formations and motions, which continue uninterruptedly, are fundamentally matching reflections of the incorporeal lights' celestial order and their relations to the world of miqdār. Particular objects that are differentiated and identified with the modes of the accidents' combination could be considered as "sculptures of miqdār"62 of the dominating lights and suspended forms (șuwar mu'allaqa) that serve as the basis of knowledge in the world of growth-decay.

\section{Conclusion}

We can consider the primary assumptions of the miqdār-based theory of body that Suhrawardi tried to develop as an alternative to the matter-form-based theory as follows:

i. Things are collections of sheer accidents in the way they are sensed/attested.

ii. There is no matter and form in the sense that the Peripatetics define.

iii. All categories like being, unity, multitude, and entity are intelligibles.

iv. Formation occurs due to perfection and deficiency, rather than potentiality and actuality.

v. There are no vacuums or atoms.

vi. The prime matter of the elemental world is self-subsistent miqdār [magnitude].

61 Ibid., 122. Suhrawardī explains retrograde movement, which was quite problematic for the classical astronomical models, in the context of the relations of radiance-motion with ease. In his words, the Peripatetic system's cosmological system, which is dual in terms of contingency and necessity and organized along ten intellects, cannot account for either the heaven of fixed stars or the multiplicity and relations of the stars and planets in the celestial sphere. According to him: “...their movements with their diversity of states are due to the correspondence of the rays and intelligible lights in their beloveds. Their relations to each other are patterned on the relations of their beloveds to each other" (Ibid., 118).

62 Taking the cue from Illuminationist psychology's description of the perceptive subject as the shapes of light, the metaphor of the "shapes of miqdār" is employed for the objects. 
The conception of body/miqdār, the justification of which is provided in The Philosophy of Illumination, is a continuum consisting of length, width, and depth. One can envision miqdār as a solely quantitative-geometric space that renders bodies apparent without recourse to external determinants like matter and form, and has no other function than to mirror the radiance of the Light of lights. There is no constituent in objects, whether simple or complex, other than the incorporeal miqdārs that could only have extension in three dimensions. The body's change and motions are explained by the one-to-one correspondence of the celestial order and motions of the infinite incorporeal lights in horizontal and vertical orders to the world of miqdārs. In the Illuminationist system, seeking a uniform universe by reducing forms of being to nūr and bodies to miqdār, a classification similar to that of the Peripatetics, immediately catches our attention: the Light of lights (necessary being), dominating lights (celestial spheres), and miqdārs/bodies (elements). However, considering that the object is just a geometric surface that appears in the relational boundary where the radiance ended relatively at the last instance, one cannot speak of an opposite substance with ontological existence other than nūr.

Suhrawardi took two important steps related to the sublunary and celestial worlds in order to unify the physical universe. First, he purified the body in the sublunary world from hypothetical constituents and reduced all of the latter to sensible quantities (i.e., miqdārs) that are regarded as one of the accidents in Peripatetic physics. The differentiation and multiplication of bodies, however, is explained by the absolute miqdār's extension at a scale of perfection and deficiency, whereas in the celestial world, the closed, finite universe consisting of intellects, souls, and celestial spheres is turned into the dominating and incorporeal lights, the numbers and layers of which reach into the hundreds and thousands in the Illuminationist vocabulary. Thus, the qualitatively divided classical universe is unified at the axis of nūr-miqdār.

The reflection of this attempt is also projected onto the theory of knowledge. The Illuminationist school's epistemic process does not seek a substance that constitutes bodies external to and beyond sensible accidents, makes their change possible, and can only be elicited by contemplation or intellection. The only condition of knowledge is unmediated beholding. The dominating light radiates over the inferior lights that adore it, and the inferior lights receiving the radiance behold to it in return. Since the contiguity of the dominating lights and those striving for it is not possible, the relation of radiance-beholding remains ongoing in the absence of a barrier between them. The difference in knowledge and ignorance has to do with the degree of removing the barriers. 
The truth of the basic motivations of the miqdār-based theory of the body and its capacity to be transformed into a quantitative natural philosophy reminiscent of the seventeenth century can be questioned. Moreover, one cannot reach a positive and certain verdict in the context of the historical conditions of Suhrawardi's time. As can be inferred, the primary cause that drove Suhrawardi to refute the matter-form-based conception of the body and to seek a miqdār-based alternative is to envision a universe that is compatible with the metaphysics of light and to remove what he viewed as problems in the way (i.e., Peripatetic dichotomies, conjectural forces, and substances).

Suhrawardi's attempt to unify the physical universe differs from modern efforts to do so in terms of its motivations and methods. The nūr-/miqdār-based Illuminationist conceptual framework might involve "modern" elements, examples of which can be seen in Descartes' wax argument and the concept of extension on the one hand, and yet it preserves the common concerns and the mindset of the twelfth century on the other. While the unification of the physical universe in the modern sense was accomplished via natural laws like gravity and Newtonian matter moves on the principle of inertia, the Illuminationists sought this unification in the direction of a metaphysical substance (nūr) by means of miqdār as an abstract continuum.

\section{Bibliography}

Amin Razavi, Mehdi. School of Illumination. London: Curzon, 1997.

Arslan, İshak. “Evrenin Sınırlarını Zorlamak: Hikmetü'l-işrak ve Şerhlerinde Meşşaî Kozmoloji Eleştirisi.” Nazariyat: Islam Felsefe ve Bilim Tarihi Dergisi 1, no. 1 (2014): 141-64.

. “Fiziksel Evrenin Bütünleştirilmesi İçin Erken Bir Teşebbüs: Sühreverdî̀nin Miktar Kavramı.” In Sühreverdi ve İşrak Felsefesi, edited by M. Nesim Doru et al. Ankara: Divan Kitap, 2015.

—_—. "Nurun Işımaları Sıcaklığın Değişimleri: İşraki Hareket Kavramı." Dîvân: Disiplinlerarası Çalışmalar Dergisi 20, no. 39 (2015): 1-22.

Cihan, A. Kamil. "Sühreverdi ve İşrakilik." In İslam Felsefesi: Tarih ve Problemleri, edited by M. Cüneyt Kaya. İstanbul: İSAM Yayınları, 2013.

Descartes, René. Meditations on First Philosophy. Translated by Michael Moriarty. New York: Oxford University Press, 2008.

Doru, M. Nesim, Kamuran Gökdağ, and Yunus Kaplan, eds. Sühreverdi ve İşrak Felsefesi. Ankara: Divan Kitap, 2015.

Fakhry, Majid. “Al-Suhravardi's Critique of the Muslim Peripatetics (al-Mashshā'ūn)." In Philosophy, Dogma and the Impact of Greek Thought in Islam, 279-84. London: Variorum, 1994.

Fazlığlu, İhsan. “Hakikat ve İtibar: Dış-dünya’nın Bilgisinin Doğası Üzerine -XV. Yüzyıl Doğa Felsefesi ve Matematik Açısından Bir İnceleme." Nazariyat: İslam Felsefe ve Bilim Tarihi Araştırmaları Dergisi 1, no. 1 (2014): 1-33.

İbn Sîna, Kitabu'ş-Şifa: Metafizik I. Translated by Ekrem Demirli and Ömer Türker. İstanbul: Litera Yayıncılık, 2004 2005 
——_. Fizik I. Translated by M. Macit and F. Özpilavcı. İstanbul: Litera Yayıncılık, 2014.

- - - Işaretler ve Tenbihler. Translated by A. Durusoy, M. Macit, and E. Demirli. İstanbul: Litera Yayıncllık, 2005.

En-Necat: Felsefenin Temel Konuları. Translated by Kübra Şenel. İstanbul: Kabalcı Yayınları, 2013.

Marcotte, Roxanne. "Suhrawardi." In The Stanford Encyclopedia of Philosophy, edited by Edward N. Zalta, Fall 2016. Metaphysics Research Lab, Stanford University, 2016. https://plato.stanford.edu/archives/fall2016/entries/ suhrawardi/.

Middleton, W.E. Knowles. A History of Thermometer and Its Use in Meteorology, Baltimore: The Johns Hopkins University Press, 1966.

al-Shirāzī, Quṭb al-Dīn. Sharh Hịkmat al-Ishrāq. Edited by 'Abdullāh Nūrānī and Mahdī Muhaqqiq. Tehran: Mu'assasah-i muțāla‘āt va taḥqīqāt-i farhangī, 2002.

Suhrawardī, Shihāb al-Dīn. The Philosophy of Illumination. Edited and translated by John Walbridge and Hossein Ziai. Provo, UT: Brigham Young University Press, 1999.

———. Hikmetü'l-işrak. Translated by Tahir Uluç. İstanbul: İz Yayıncılık, 2009.

Nur Heykelleri. Translated by Saffet Yetkin. İstanbul: MEB, 1949.

Turğay, Fatma. "İşraki Felsefe Geleneğinde Misal Alemi: Sühreverdi Örneği.” Unpublished PhD diss., İstanbul University, İstanbul, 2016.

Uluç, Tahir. Sühreverdînnin İbn Sîna Eleştirisi. İstanbul: İnsan Yayınları, 2012.

Ziai, Hossein. “Al-Suhrawardi." Encyclopaedia of Islam. New ed., vol. 9: 782-784. Leiden: Brill, 1997.

Knowledge and Illumination: A Study of Suhrawardi's Hikmat al-Ishraq. Atlanta: Scholars Press, 1990. 